\title{
OPPORTUNITIES OF MEDIA EDUCATION IN QUALIFICATION TRAINING FOR EDUCATORS
}

\author{
Veronica YARNYKH*, Russian State University for Humanities, Russian \\ Federation
}

Přijato: 18. 5. 20XX / Akceptováno: 12. 6. 2017

Typ článku: Teoretická studie

DOI: $10.5507 /$ jtie.2017.013

Abstract: The modern information society and global cooperation in the world are set new requirements for the role and competence of the educators at any level. One of the main focuses is developing of media competence. The conditions of existence in modern society are the life in the media space. The use of media in the system of educators' training allows creating media competence of educator at any level of education efficiently and effectively. The aim of the manuscript is to determine the possibilities of media education in a non-core area as an upgrade of the qualifications of teachers of any level.

Key words: professional training and development of educators, media education, media education's tools and technologies, media competency.

\section{ROZVOJ MEDIÁLNÍCH KOMPETENCÍ V RÁMCI UČITELSKÉ PŘÍPRAVY}

Abstrakt: Moderní informační společnost a celosvětová spolupráce položila nové požadavky na úlohu a kompetence pedagogů všech stupñu vzdělávání. Jeden z mnoha cíli této výchovy je rozvoj mediální gramotnosti (mediální kompetence). Podminkou existence v moderní společnosti je život v mediálním prostoru. Použití médii $v$ systému učitelské prípravy umožňuje efektivni rozvoj mediálnich kompetencí učitelů všech stupňů vzdèlávaci soustavy. Cílem článku je determinovat př́ležitosti $k$ rozvoji mediálnich kompetenci a rozpracovat tak kvalifikační rámec učitelì.

Kličcová slova: odborná př́prava a rozvoj pedagogů, mediální výchova, nástroje a technologie mediální výchovy, mediální kompetence.

*Autor pro korespondenci: vyarnykh@gmail.com 


\section{Introduction}

We live in the media world. The modern world is a world of media and information. The main production resource in the modern information society is information. This is both a potential and a resource for development. Information is present in our life in different ways and forms. One of the forms of presence is the world of media. Media competence of the modern educator is one of the main competences in the professional profile. Working and communication with Generation $\mathrm{Z}$ it's necessary to speak and use habitual society language and tools.

The modern world, and the world of media, including, significantly changed the activities of a modern educator. In today's world there are many global factors impact on education in general and media education in particular. The modern system of education and the learning process is under huge pressure from the global factors of influence. Vis Naidoo (Vis Nadoo, 2014) notes that modern education has maximum influence on these global factors:

- Changes in the economic and social requirements. According to research by the University of Oxford more than $47 \%$ of jobs in the next decade will be automated. You also need to talk about the growing influence of employers that focus on getting ready professionals in the industry, whose adaptation of the work will take less time, and so will save money and financial resources.

- An increase in the process of training costs and training resources. In this connection it is necessary to pay attention to the possibility of massive online learning (MOOC), for example. By 2025, the expected 263 million tertiary education students, which have also a significant impact on the economy of countries and their investment in higher education

- Constantly and rapidly changing digital- technology. This technical development has a direct impact on the competence model of the modern university graduate, and therefore the future specialist in the labor market. But the technology also provides access to tertiary (higher) education and provides knowledge process of massification. An example is the Coursera or MIT project on computation in the open access of the array of lecture material.

These global drivers of change and the changing educational environment, the development of information society and digital - technologies could not exert any influence on the change and the role of the teacher at any level.

For example, a research review of the Economist (Economist, 2008) includes the following change of focus:

- Technologies have and will continue to have a significant impact on higher education. And consider this factor, in particular, and in the system of training is necessary. $63 \%$ of the survey participants said that in the last five years it was one of the main factors of influence and development.

- $\quad$ On-line training is gaining strong positions in universities around the world. It provides including the massification of higher education

- Corporate Academic Partnership is a significant part of the experience of the modern university.

- The globalization of higher education in general. 


\section{Media competence of educators}

It should be noted that much has changed and the role of the teacher at any level. Some researches (Aiga von Hippel, 2010) and (Eva Ujlakyné Szücs, 2010) pointed out that even in the XX century, the educator was a major source of knowledge and information, the leader of the school of life, organized after-school activities, and served the role of parents. Now the query society on the role of the teacher was changed. With the development of information and educational space, he must learn how to seek and receive information on how to select and use. In the context of today's knowledge society the media becomes a fundamental competence in professional and everyday life. In this context, the role of the educator in the educational organizations of all levels is changing. In the process of teaching the educator becomes a facilitator and moderator of the process. And finally, the modern teacher is an agent of social change. Thus, it should be noted that the development of new competencies of the modern teacher, among which an important role is played by the media competence, becomes necessary. The profile of modern media competencies could be extremely diverse. For example, some authors note that the major media competence may look like this (Jennifer Tiede, Silke Grafe \& Renee Hobbs, 2015):

1. To help students use educational web-based tools to solve problems and communicate information in a digital format with experts, peers and educators.

2. Know the basic tools and Web 2.0 and Web 3.0 technologies.

3. Use the educational sites and social networking sites to communicate with colleagues, students and their parents.

4. Have the navigation skills evaluation and professional content creation applications on network resources.

5. Use online resources to create, maintain and teach the students. Also, use online resources for self-learning and self-development.

6. Know the principles of on-line resources, to follow the netiquette, comply with the ethical norms and principles, and to interact appropriately with others, especially with students on the Internet.

7. Understand and know the problems of copyright, security and privacy on social media sites and to share this insight with students and professional colleagues.

8. Understand the importance of identity management and reputation through social media and to help students understand the long-term impact of placing personal information on the Internet.

9. Create and develop an individual learning plan to stay abreast of trends, tools, and social media applications.

10. Participate in the development of educational policies and guidelines of different levels

Also these researches (Jennifer Tiede, Silke Grafe \& Renee Hobbs, 2015) note that media pedagogical competences are defined as the interaction of three areas, namely:

- $\quad$ Media didactics (use of mass media to stimulate and support learning processes);

- Media education (when performing media-related educational and training tasks);

- Development of the school (use of the media for tasks related to the development of the educational organization).

Each of these areas is further divided into five qualifying aspects, among which:

1. Understanding and evaluating conditions 
2. Description and evaluation of theoretical approaches

3. Analysis and evaluation of relevant examples and expertise

4. Development of proposals based on their own theoretical basis

5. Implementation and evaluation of the theory on the basis of practical examples.

Thus, it should be noted that the media competence of the teacher includes not only the ability to work full-scale with information in modern media space, but also the ability and develop this competence among students. In fact, it is the competence of existence in the modern media world. In addition, it's important to note that UNESCO defined media education as a priority area of cultural and pedagogical development in the 21 st century.

It should be specially noted that media education at the moment is a concept of interdisciplinary and convergent. A variety of approaches makes media education a convergent direction in education at the junction of media, education, ICT, etc.

The difference of approaches focuses on media literacy, media security, information literacy, information security, etc. UNESCO since 2014 speaks about the general concept of both media and information literacy. This creates the convergent nature of media education on the one hand. On the other hand, this approach creates opportunities for the integrated use of tools and technologies, ensuring the implementation of various aspects of media education in professional development programs, for example.

Similar to the UNESCO recommendations for ICT - literacy of the educator, it is necessary to pay attention to the following components in the field of media education: understanding the role of media education in education in general, the content of curricula and evaluation of results and quality, pedagogical practices, technical and software tools for media education, management of educational processes And the professional development of the teacher (UNESCO, 2015). It is the latter that seems to be one of the main focuses of development in the modern educational environment.

As Steve Connolly (Steve Conolly, 2013) notes, media education technology is widely used in schools, but not so developed in higher education. This further increases the distance between the teacher and the student both at school and at the university. And this also becomes one of the factors of the need to change the program of professional development taking into account the requirements of media education.

As some researchers note, for example, Alice Y. L. Lee (Alice Y. L. Lee, 2016) media education is "the process of teaching and learning about media", media literacy is the outcome. Media literacy consists of a series of communication competencies, including the ability to access, analyze, evaluate, create, and act using all forms of communication. In brief, media literacy and the $4 \mathrm{C}$ skills (critical thinking, creativity, communication, and collaboration) are crucial for students to survive in the contemporary society.

Thus, it should be noted that the media competence of the teacher includes not only the ability to work full-scale with information in the modern media space, but also the ability and develop this competence among students. In fact, this is the competence of human existence in the modern media world, which is formed and develops at all levels of education.

Competence approach now is the global influence factor in educational space. Some researches (Katie Larsen McClarty\&Matthew N. Gaertner, 2015) note the influence of the main focuses of the modern information society in the formation of the profile of competences of university students. There are: 
- Automation;

- Globalization;

- Changes in the workplace;

- Demographic changes;

- Personal risk and responsibility for the decisions - making.

Importantly, under the influence of these parameters competence approach is used learning transforms, and at the level of the integral. Competence approach means, above all, flexibility and variability in the process of vocational education and training. This approach provides a rapid response to changes in the labor market, employer requirements, changing requirements of educational standards and the level of any generation.

In order to take into account all the necessary interests and ensure the process of improving the qualifications of educators in accordance with the current level of development of the information environment, it is necessary to take into account the following points.

Speaking about post-graduated education and later professional development of educators of any educational level it's important to mention that new world, media environment and changes in the role of teacher in society and new requirements to professional profile needs new approaches to the educational process.

It should be noted that the modern information society requires fundamentally new approaches to the technologies for improving the qualifications of teachers. In general, the most important are three approaches to the formation of a system of teacher training:

- Modular approach based on the formation of a training program and the development of skills in modules. This makes it possible to form an individual educational trajectory for each teacher, which is the basis of the knowledge society.

- Systematic approach that considers the development of skills in relation to other production and educational processes. This approach allows us to form a single educational space on the one hand, and build a long-life learning process (lifelong learning).

- Activity-oriented approach, aimed at the formation and development of individual processes, activities, professional competencies, etc. This view allows you to "hone" individual skills and skills, focus on individual competences or their blocks in the competency model.

Almost all models of professional development of educators of any level in one form or another focus on the following points:

- Implementation of modular programs focused on the competence approach and the development by educators in the process of professional development of effective ways of solving professional problems;

- Revealing of inquiries of consumers of educational services taking into account all levels of order formation;

- Variability and targeting of professional development, suggesting the flexibility and diversity of the content and forms of the organization of training used and allowing to fully take into account the needs and opportunities of students; 
- Individualization of the process of professional development on the basis of building individual educational trajectories and ensuring the continuity of professional development;

- Openness of the system of professional development, monitoring of activities and evaluation of the quality of educational services provided.

Modern trends in the development of education actualize attention to the development of distance educational technologies. The development of the system of distance education of educators is based on the conceptual foundations of open, variable and continuous education and involves the integration of various teaching technologies, which is aimed at improving the effectiveness of the educational process aimed at the fullest satisfaction of students' needs.

In this regard, it is important to note that the tools and technologies of modern media education provide a good opportunity to implement these tasks.

The modern educational process does not simply include a sufficiently large media component, but is based on information technology, allowing the development of a competence approach.

It is also important to pay attention to the use of distance technologies in the development of educators at any level. It is in this format is most convenient and effective use of media education technologies.

Forming a unified educational environment, opportunities for communication and interaction on a vertical and horizontal level make it possible not only to solve the educational tasks of the refresher course, but also to develop the necessary media competencies. It is important to emphasize that the tools for this is enough.

The organization of continuous professional development on the basis of the cascade model is now inextricably linked with the development and use of distance educational technologies, which allows educators of any level to improve their professional competence on the job, to build an individual educational route in accordance with professional needs and time opportunities, effective use of information and media technologies in pedagogical practice.

The distribution of training in the context of the implementation of the cascade model of professional development allows to expand the educational space, to diversify the information and educational support of the educational process (specialized databases, electronic educational resources, computer audio and video materials), to organize an accessible 24/7 communication space, using various information services: videoconferences, forums, e-mail, IP-telephony to provide professional support of professional development of educators.

During the preparing and conduct refresher educational course for directors of the Moscow educational complexes there were used two ways of using methods and tools of media education.

From one side it's possible to use and include media products in modern educational process. From another side it's possible to use methods of media education.

For realization the sub-aims of process it could use and include two announced ways.

Participants of several groups used following tools and technologies:

- Implementation of real media projects of the training system; 
- The formation of unified educational and media space for groups of participants. In practice, groups used social networks, messengers. This allows for including the possibility of mutual consultation of program participants;

- The master - classes of successful participants with the idea of best practices;

- The use of multimedia resources in the learning process;

- The use of case - study, modeling and other innovative technologies in teaching practice.

Among them they're as methods of technical support but also the methods of communication, presentation and discussion.

It's necessary to mention as results that the interest for such study was really high.

The discussion of real experiences of participants and analysis and consulting of real media projects (websites, press-releases, events, etc.) allowed in the context of the consultation came to good results. In feedback practically all of participants (90\%) mentioned that exactly such approach was the most useful for them, could save time, efforts and gave opportunity to know another expertise, achievements and problems.

From another side on the results of such work it possible to make the changes in program but also to increase the using of media education's methods and tools in refresh educational programs.

However, it would like to note that the programs that include approaches in the field of media education are not widespread in Russia.

For the directors of the Moscow educational complexes such program was prepared. It includes media technologies and tools for the formation and development of the image and brand of the school complex in the media space. But this is only one side.

At some pedagogical faculties of the Russian educational space, there are elective courses in media education, but this is also not a mass one.

The educational space for advanced training for those educators who already are working in schools, colleges and universities practically does not include the area of media education.

\section{Conslusion}

In the conclusion, it would like to mention that due to the changing role of the educator in the educational sphere, the global factors of influence on the educational environment, and taking into attention the influence of the media in the modern world so system of teacher training is also undergoing tremendous changes.

For the formation and development of the modern profile of educator's competencies necessary to make full use of the global approach, as well as the tools and technology of media education.

Mankind lives in the media world, gets used to certain opportunities. Under these conditions, the influence of global factors, the competence model of a modern educator of any level also fundamentally changes. Media and educational spaces do not just intersect, but form a single whole. And the ability to work and exist in it, as well as the ability to teach it to use, becomes a necessity for a modern educator.

With regard to curriculum changes in the field of professional development, they can be either a separate course or be associated with ICT skills training programs.

Proceeding from the foregoing, it should be noted that the program of professional development must necessarily contain mainly theoretical part with practical content 
relating to the current trends in the development of media education, the reputation of the educator in the media world. This is the course "Introduce in media education" as I lead as a professor.

The second type of the course can be aimed at practical technical skills and the development of practical media competencies. There is a consistent relationship with ICToriented programs. Such courses are aimed at introducing specific practical skills of using modern media tools to the work of the educator.

\section{References}

Vis Nadoo. Drivers for changes in higher education. Year 2014. - [electronic resource] https://www.col.org/news/speeches-presentations/drivers-change-higher-education

The future of higher education: How technology will shape learning report from the Economist Intelligence Unit Sponsored by the New Media Consortium. Year $2008-$ p.6 (Electronic assess) https://www.nmc.org/pdf/Future-of-Higher-Ed-(NMC).pdf Aiga von Hippel. Subjective concepts of media. The University of the Fraser Valley Research Review. Year 2010, volume 3: issue 2 (Spring). - pp. 69 - 80. ISSN 1715-9849 Eva Ujlakyné Szücs. The role of educators in the 21st century. Revue internationale International Webjournal. Year 2010, N 9. ISSN 2104-3272

Jennifer Tiede, Silke Grafe \& Renee Hobbs. Pedagogical Media Competencies of Preservice Educators in Germany and the United States: A Comparative Analysis of Theory and Practice. - Peabody Journal of Education. Year 2015, N 90(4) - pp. 533-545 UNESCO ICT Competency Framework for teachers. Paris. UNESCO. Version 2.0. France. 2011, 2013, 2015. - 92 p. ISBN 978-92-3-01053-9

Connolly S. Media Education: A Tool for Social Inclusion. In: Fraser P., Wardle J. (eds) Current Perspectives in Media Education. Palgrave Macmillan, London, 2013 - pp.41-54. DOI: 10.1057/9781137300218_4. ISBN 978-1-349-45305-4. ISBN 978-1-137-300218ise.?.

Alice Y. L. Lee. Media education in the School 2.0 era: Teaching media literacy through laptop computers and iPads. Global Media and China. Volume: 1 issue: 4, 2016 - pp. 435449. DOI: $10.1177 / 2059436416667129$

Katie Larsen McClarty, Matthew N. Gaertner. Measuring Mastery. Best practices for assesment in competency-based education. Center for College \& Career Success, Pearson. Year 2015. - p.20

(Electronic mastery.pdf assess)https://www.luminafoundation.org/files/resources/measuring- 